\title{
Antenatal diagnosis of intracranial haemorrhage and porencephalic cyst
}

\author{
T Williams, ${ }^{1}$ A G Wilkinson, ${ }^{2}$ J Kandasamy, ${ }^{3}$ S Cooper, ${ }^{1}$ J P Boardman ${ }^{4}$
}

'Simpson Centre for Reproductive Health, Royal Infirmary of Edinburgh, Edinburgh, UK

${ }^{2}$ Department of Radiology, Royal Hospital for Sick Children, Edinburgh, UK ${ }^{3}$ Department of Neurosurgery, Royal Hospital for Sick Children, Edinburgh, UK ${ }^{4}$ University of Edinburgh / MRC Centre for Reproductive Health, Edinburgh, UK

\section{Correspondence to} Dr T Williams,

thomascwilliams83@ googlemail.com

Accepted 14 January 2015
CrossMark

To cite: Williams T, Wilkinson AG, Kandasamy J, et al. BMJ Case Rep Published online: [please include Day Month Year] doi:10.1136/bcr-2014209130

\section{DESCRIPTION}

A 27-year-old woman was referred at 37 weeks' gestation for confirmation of malpresentation. Incidental hydrocephalus was found on ultrasound. Fetal MRI confirmed dilation of the lateral and third ventricles and an extensive mixed signal intensity cystic structure in the left hemisphere $(7 \times 6 \times 4 \mathrm{~cm})$ with evidence of blood products and restricted diffusion (figure 1A). The maternal platelet count was $114 \times 10^{9} / \mathrm{L}$, and maternal antibody testing for neonatal alloimmune thrombocytopaenia (NAIT) was positive (anti-HPA (human platelet-specific antigen) 1a alloantibodies, maternal genotype HPA 1bb, paternal genotype HPA 1ab).

Subsequently a live female infant was delivered by caesarean section. At birth the infant had widened sutures and a petechial rash. The platelet count was $4 \times 10^{9} / \mathrm{L}$ and the infant received two HPA1a-negative platelet transfusions shortly after birth. MRI the next day confirmed posthaemorrhagic ventricular dilation and a large haemorrhagic

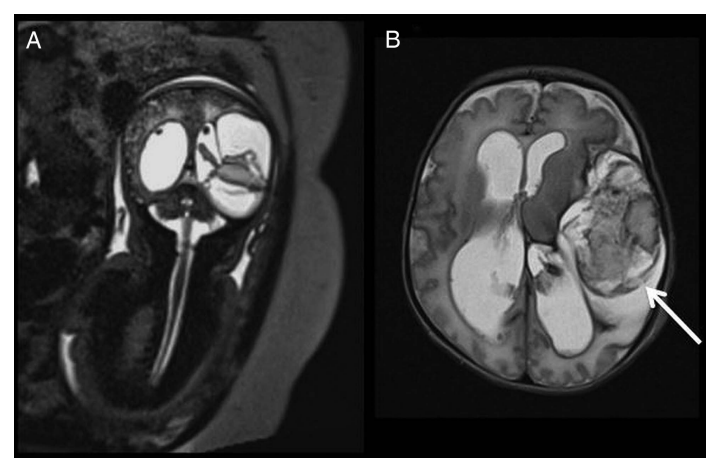

Figure 1 (A) Antenatal MRI. (B) Postnatal MRI day 1. parenchymal infarction with porencephalic cyst (figure $1 \mathrm{~B}$, arrow). She required a cystoventriculoperitoneal shunt at 4 weeks.

NAIT is an IgG mediated disorder that occurs after maternal exposure to incompatible fetal paternally derived platelet antigens; it can occur in first pregnancies. ${ }^{1}$ Outcomes for NAIT with intracranial haemorrhage $(\mathrm{ICH})$ are poor: registry data suggest that only $12 \%$ of children with $\mathrm{ICH}$ secondary to NAIT survive without significant neurodisability. ${ }^{2}$ Detailed antenatal imaging and testing for NAIT when fetal intracranial haemorrhage is suspected enables planned early treatment with matched platelets if the diagnosis is confirmed, which minimises the duration of postnatal profound thrombocytopenia and risk of further haemorrhage.

Contributors TW devised idea for article, selected appropriate images and drafted the text. GW selected appropriate images for article and contributed to text. JK revised the text for important intellectual content. SC revised the text for important intellectual content. JPB devised idea for article, selected appropriate images and drafted the text. All authors approved the final submitted version.

Competing interests None.

Patient consent Obtained.

Provenance and peer review Not commissioned; externally peer reviewed.

\section{REFERENCES}

1 Peterson JA, McFarland JG, Curtis BR, et al. Neonatal alloimmune thrombocytopenia: pathogenesis, diagnosis and management. $\mathrm{Br} J$ Haematol 2013:161:3-14.

2 Tiller $\mathrm{H}$, Kamphuis MM, Flodmark O, et al. Fetal intracranial haemorrhages caused by fetal and neonatal alloimmune thrombocytopenia: an observational cohort study of 43 cases from an international multicentre registry. BMJ Open 2013;3: pii:e002490.

Copyright 2015 BMJ Publishing Group. All rights reserved. For permission to reuse any of this content visit

http://group.bmj.com/group/rights-licensing/permissions.

BMJ Case Report Fellows may re-use this article for personal use and teaching without any further permission.

Become a Fellow of BMJ Case Reports today and you can:

- Submit as many cases as you like

- Enjoy fast sympathetic peer review and rapid publication of accepted articles

- Access all the published articles

- Re-use any of the published material for personal use and teaching without further permission

For information on Institutional Fellowships contact consortiasales@bmjgroup.com

Visit casereports.bmj.com for more articles like this and to become a Fellow 